Article

\title{
Comparing Methods of Evaluation of Geosites: The Fossiliferous Outcrops of Santa Maria Island (Azores, NE Atlantic) as a Case Study for Sustainable Island Tourism
}

\author{
Vera B. Raposo ${ }^{1,2,3}$, Carlos S. Melo ${ }^{1,3,4,5}$ (D) Luís Silva ${ }^{1,2}$, Anunciação Ventura ${ }^{1,2}$, Rita Câmara ${ }^{6}$, \\ Joana Pombo ${ }^{7}$, Markes E. Johnson ${ }^{8}$ and Sérgio P. Ávila ${ }^{1,2,3,9, * \mathbb{C}}$ \\ 1 CIBIO—Centro de Investigação em Biodiversidade e Recursos Genéticos, InBIO Laboratório Associado, \\ Pólo dos Açores, 9500-321 Açores, Portugal; verinha_raposo@hotmail.com (V.B.R.); \\ casm.azores@gmail.com (C.S.M.); luis.fd.silva@uac.pt (L.S.); maria.am.ventura@uac.pt (A.V.) \\ 2 Departamento de Biologia, Faculdade de Ciências e Tecnologia, Universidade dos Açores, \\ Campus de Ponta Delgada, Apartado 1422, 9501-801 Ponta Delgada, Açores, Portugal \\ 3 MPB-Marine PalaeoBiogeography Working Group of the University of the Azores, \\ 9500-321 Rua Mãe de Deus, Portugal \\ 4 Departamento de Geologia, Faculdade de Ciências da Universidade de Lisboa, Apartado, \\ 1749-016 Lisboa, Portugal \\ 5 Instituto Dom Luiz, Faculdade de Ciências, Universidade de Lisboa, 1749-016 Lisboa, Portugal \\ 6 Parque Natural de Santa Maria, Serviço de Ambiente da Ilha Santa Maria, Rua Dr. Teófilo Braga \\ n 10/12/14, 9580-535 Vila do Porto, Portugal; rita.mt.camara@azores.gov.pt \\ 7 Centro de Interpretação Ambiental Dalberto Pombo, Rua Teófilo Braga, nº 10/12/14, \\ 9580-535 Vila do Porto, Portugal; Joana.PS.Tavares@azores.gov.pt \\ 8 Department of Geosciences, Williams College, Williamstown, MA 01267, USA; mjohnson@williams.edu \\ 9 Faculdade de Ciências da Universidade do Porto, Rua do Campo Alegre 1021/1055, 4169-007 Porto, Portugal \\ * Correspondence: Sergio.pa.marques@uac.pt; Tel.: +351-296-652-100
}

Received: 1 September 2018; Accepted: 8 October 2018; Published: 9 October 2018

check for updates

\begin{abstract}
The increasing interest in geotourism has prompted the need for quantitative assessments of geosites as a fundamental step in the application of geoconservation strategies, in order to assure sustainable planning, management and use of natural resources. The improvement of methodologies used to evaluate geosites dictates the revision of previous assessments on a regular basis. Santa Maria Island in the Azores Archipelago is renowned for its palaeontological heritage. Herein, we present the results of a re-evaluation of 17 fossiliferous geosites, based on an updated methodology in which four main independent criteria are considered: (1) scientific value; (2) educational value; (3) touristic value; and (4) degradation risk. These new results were compared with a previous evaluation of the same geosites, based on the Q-value. Our results show that an evaluation of the fossiliferous geosites based on independent criteria is more suitable, especially for political and economic stakeholders. The study of these geosites also permitted the development of high-quality promotional products for the Regional Government of the Azores, as in the case of the "House of the Fossils" museum, the "Fossils Route" and the newly formed "Santa Maria PalaeoPark," making this island a good example of a successful joint venture between science, political decision-makers, geoconservation management strategies, sustainable tourism and education.
\end{abstract}

Keywords: Santa Maria Island; Azores; geoconservation; assessment; geosites; management strategies; sustainable tourism; education 


\section{Introduction}

The term "geodiversity" was first used by geologists during the 1993 Malvern Conference on Geological and Landscape Conservation in the context of "variety within abiotic nature" [1]. Currently, geodiversity is defined as the natural diversity of earth materials, encompassing geological (rocks, minerals, fossils), geomorphological (landforms, topography, physical processes), soil and hydrological features [1], all representing abiotic elements [2].

Geosites (i.e., in situ geodiversity elements with high scientific value [2]) hold scientific, educational, historical, cultural and recreational interests, and contain information about the state and the dynamics of the Earth, whereas palaeogeographical geosites (i.e., geosites representing palaeoenvironments, many of them containing fossils and/or ichnofossils), hold interest for science, tourism and educational purposes [3,4]. These sites are exposed to natural and anthropogenic influences and must be protected for their value. The set of geoconservation strategies designed to protect geological heritage is focused on the management of the geological elements (e.g., rocks, minerals, fossils, sedimentary sequences, folds/faults) present at the geosites [5] with the aim of maintaining: (1) geodiversity, retaining significant representative examples; and (2) natural rates and magnitudes of change, i.e., the capacity of natural systems to change and evolve in natural ways [6]. In situ conservation of the most important geosites and palaeogeographical geosites (sensu $[2,3])$ is an important task as it provides present and future generations of researchers the opportunity of understanding the Earth's history, past environmental changes, geological phenomena and the evolution of (palaeo)organisms $[7,8]$.

According to [9], geotourism may be defined as "a form of tourism based on the geological environment." This relatively new concept is related to and incorporates ideas taken from correlative research areas such as geodiversity, geoheritage, geoconservation, and tourism geotours. As a result of this holistic approach, which combines environmental and cultural issues, the final goal of geotourism is to reach and maintain sustainable tourism development, using the most relevant geological elements present in a particular landscape.

During the last few decades, several attempts have been made to evaluate the quality of geoheritage in various contexts, and in the literature numerous methods are described for the quantitative assessment of geosites, e.g., [10-15]. Brilha [2] recently developed a new framework for the inventory and quantitative assessment of geosites and palaeogeographical geosites, aiming for the implementation of geoconservation procedures in geoparks, worldwide (see also [16-18]). The aim of this contribution is to update and compare previous results obtained on the quantitative assessment of the palaeogeographical geosites of Santa Maria Island (Azores) [19], with those using the new methodology proposed by Brilha [2]. This specific method [2] was selected because it is a logical development of a previous version [19], which was successfully adapted to an oceanic island setting such as the Azores, and tested with good results.

\section{The Azores Archipelago: Geographic and Geotectonic Setting}

The Azores is a volcanic archipelago located in the NE Atlantic Ocean, approximately $1500 \mathrm{~km}$ west of the shores of mainland Portugal (Figure 1). The archipelago has a WNW-ESE general trend, with about $615 \mathrm{~km}$ separating the most distant islands (Flores and Santa Maria), and is composed of a set of nine volcanic oceanic islands that straddle an area where three major tectonic plates converge-North American; Eurasian; and Nubian—known as the Azores Triple Junction [20]. This triple junction is, in general terms, bounded by the Mid Atlantic Ridge (MAR) to the west, the Terceira's Rift and Gloria Fault to the northeast and east (the last two are the western and central parts of the Azores-Gibraltar Fracture Zone), and the East Azores Fracture Zone to the south [21]. The islands rise from a prominent bathymetric anomaly, termed the Azores Plateau, with depths shallower than expected within a plate tectonics setting [22]. 

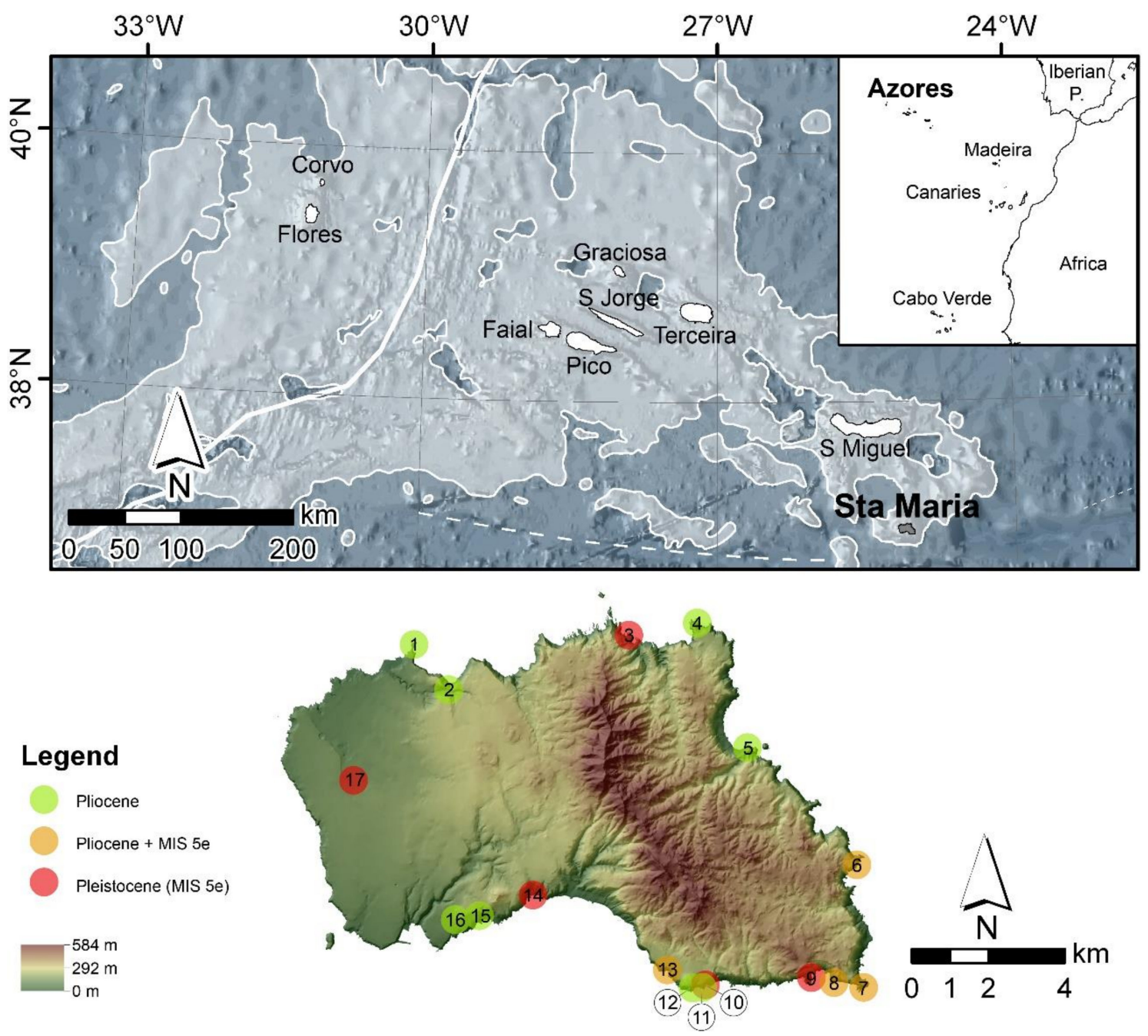

Figure 1. Top: location of the Azores Archipelago in the Northeast Atlantic. The light blue area represents the Azores plateau (see text). Bottom: location of the most important Pliocene and Pleistocene palaeogeographical geosites (fossiliferous outcrops) of Santa Maria Island: 1-Ponta dos Frades; 2-Cré; 3-Lagoinhas; 4-Ponta do Norte; 5-Ponta Negra; 6-Ponta do Cedro; 7-Ponta dos Castelo; 8-Pedra-que-pica; 9-Vinha Velha; 10-Pedrinha da Cré; 11-Baía de Nossa Senhora; 12-Malbusca; 13-Ichnofossils' cave; 14-Prainha; 15-Figueiral; 16-Pedreira do Campo; 17-Airport area. The Pleistocene outcrops are restricted to the warmest interval of the Last Interglacial Period ( 130 ka to $116 \mathrm{ka}$ ), which is known as MIS 5e-Marine Isotopic Substage 5e.

\subsection{Santa Maria Island: Geological and Palaeontological Studies}

Santa Maria is the oldest island of the Azores Archipelago, having emerged above sea level during the Late Miocene, at about $6 \mathrm{Ma}$. The geological history of this island is complex, with a subsidence trend from $6 \mathrm{Ma}$ to about 3.5 Ma at a rate of $100 \mathrm{~m} / \mathrm{Ma}$, followed by an uplift trend from 3.5 Ma to the present at a rate of $60 \mathrm{~m} / \mathrm{Ma}$ (for a review, see [23]). The first island of Santa Maria was probably completely eroded and a large, shallow, submarine bank was created, where marine life thrived in both variety and abundance. In recent years, the geology and palaeontological record of Santa Maria have been studied in detail. These works led to detailed knowledge regarding the location of the most important fossiliferous outcrops (see Figures 2-5), as well as the biological composition and ages of their palaeocommunities. Currently, 204 Pliocene and 146 Pleistocene (MIS 5e) species and at least 15 to 20 ichnospecies are reported for the island, ranging in size from megavertebrates (e.g., whales and sharks [24-26]) to macrovertebrates (e.g., ray fishes [27]), and from macroinvertebrates (e.g., molluscs, sea urchins, barnacles, annelids [28-31]) to microinvertebrates (e.g., molluscs, brachiopods, bryozoans, 
ostracods [32-36]), including marine algae as well [37-39]. For a recent review of the most significant fossiliferous outcrops of Santa Maria Island, please see [40].
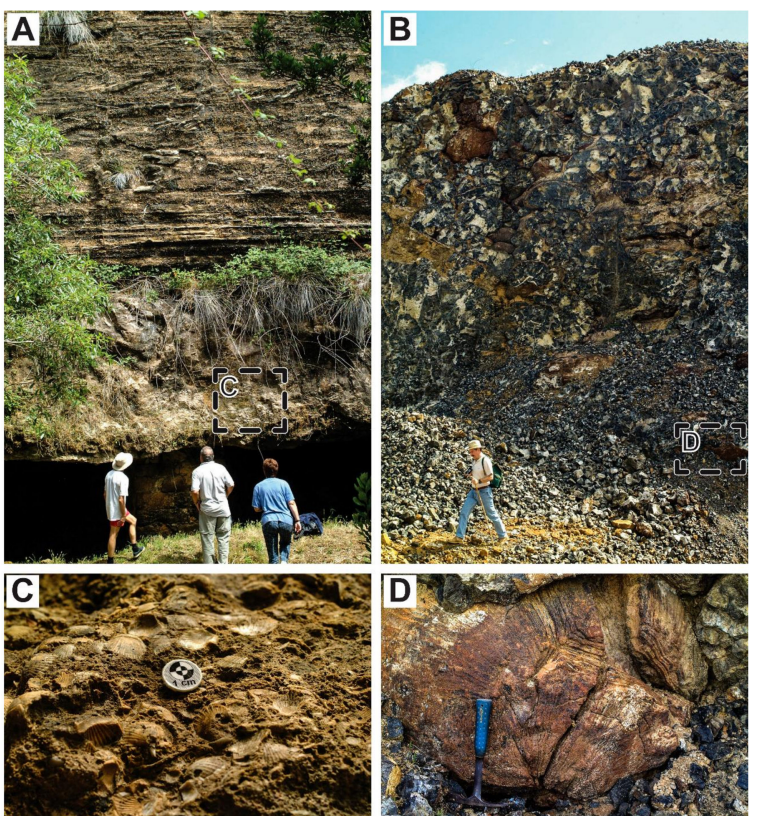

Figure 2. Fossiliferous geosites at Santa Maria Island. (A) Figueiral (Pliocene); (B) Pedreira do Campo (Pliocene); (C) detailed view of the Figueiral outcrop, with disarticulated valves of Aequipecten macrotis (Sowerby, 1847) and Aequipecten opercularis (Linnaeus, 1758); (D) detailed view of a pillow lava from Pedreira do Campo outcrop, with the characteristic glassy texture; the pillow lavas cover the Pliocene fossiliferous layer. Pedreira do Campo was the first fossiliferous geosite to be classified, in 2003, as a Regional Natural Monument in the Azores.
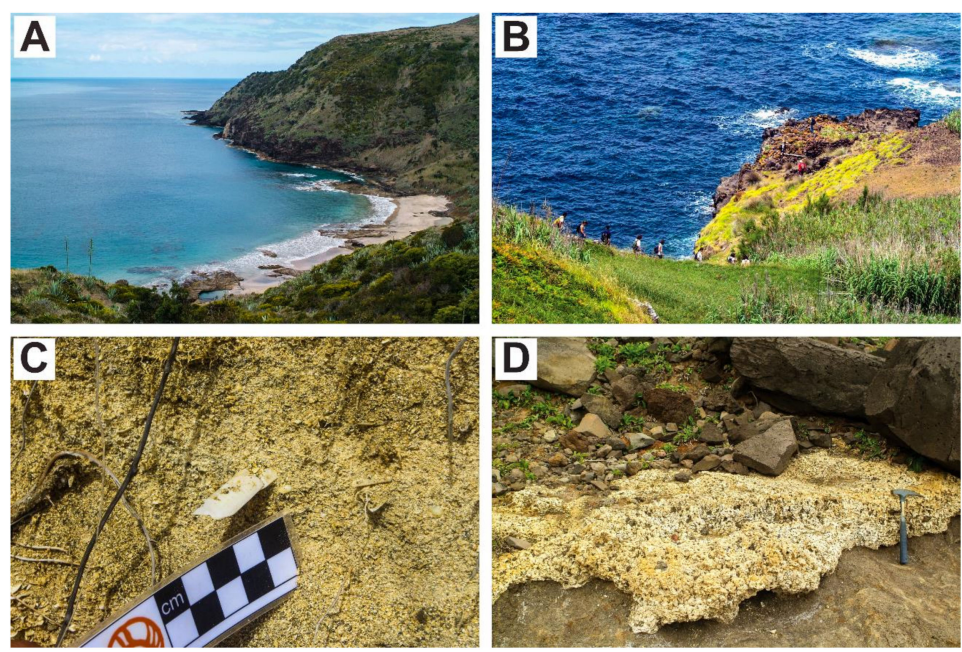

Figure 3. Fossiliferous geosites at Santa Maria Island. (A) Prainha (Pleistocene, Last Interglacial); (B) Lagoinhas (Pleistocene, Last Interglacial); (C) detail of the sandy fossiliferous layer at Prainha, with an exposed valve of the bivalve Ensis minor (Chenu, 1843); (D) detail of the fossil algae layer at Lagoinhas. The access to these geosites is done through hiking trails included in the "Fossils Route."

\subsection{Geoheritage Studies in Santa Maria Island}

The first inventory and characterization of the Azorean geosites [41] was later complemented by a large team whose work led to the Azores Geopark application to the ENGG (European Network and Global Geoparks) [42] and, more recently, by Lima and co-workers [43], based on a geological heritage management approach. Santa Maria Island was initially proposed with eight selected 
geosites [41], which were revised to 15 [44,45] and, recently, to 26 [19], 17 of which have palaeontological interest. Of these 17 palaeogeographical geosites, two are of international relevance and six of national relevance [19]. Based on the rarity of coquina and of tempestite deposits on volcanic oceanic islands, the two geosites with international relevance (the fossiliferous outcrops of Pedra-que-pica and of Ponta do Castelo), were recommended to the Regional Government of the Azores for classification as Regional Natural Monuments [19].

The pioneer work of Brilha [46] led to the development of a quantitative system of classification for geosites based on three criteria: A-Intrinsic criteria to the geosite; $\mathrm{B}$ - criteria related to potential uses of the geosites; and C-criteria related to the necessity of protection of the geosite. These criteria were calculated in a formula and the result was represented by a letter, $Q$. This methodology was adapted to the insular context [41], making it possible to obtain a ranking of a geosite's relevance based on the $Q$-values.

More recently, Brilha [2] published a new methodology of inventory and quantitative assessment of geosites that aims to reduce the subjectivity on attributing values to each parameter (see also [47,48]). The quantitative assessment is thus made independently for each criterion (scientific value; potential educational use; potential touristic use; and degradation risk) and each parameter has a different weight. Following the publication of this new methodology, we intend to re-evaluate the relevance ranking of the fossiliferous geosites of Santa Maria by comparing the results obtained by Ávila and co-workers [19] and our new values, in order to verify whether or not the application of this methodology changes the position of the geosites in rank of relevance.
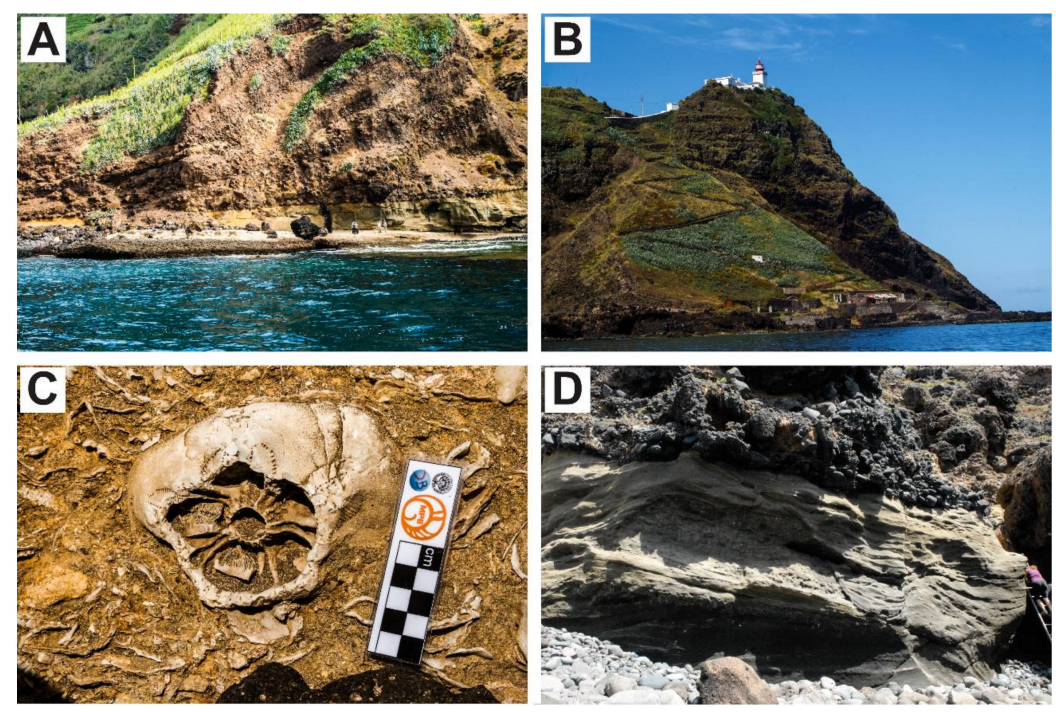

Figure 4. Fossiliferous geosites at Santa Maria Island. (A) Pedra-que-pica (Pliocene and Pleistocene, Last Interglacial); (B) Ponta do Castelo (Pliocene and Pleistocene, Last Interglacial); (C) Clypeaster altus (Leske, 1778) outcropping at the Pedra-que-pica coquina; (D) partial view of the tempestite deposit at Ponta do Castelo. Pedra-que-pica displays one of the largest multi-specific Pliocene coquina ever reported from a volcanic oceanic island [26]. Ponta do Castelo shows a well-preserved hummocky structure, which led to a better comprehension of the main processes responsible for the transport and deposition of sediments around open-sea oceanic volcanic islands during the Pliocene [49].

\section{Materials and Methods}

Re-Evaluation of Santa Maria's Geosites

A total of 17 fossiliferous geosites from Santa Maria Island were selected and their relevance quantified: Prainha, Pedra-que-pica, Pedreira do Campo, Figueiral, Ponta do Castelo, Ichnofossil's Cave, Malbusca, Ponta do Cedro, Ponta dos Frades, Lagoinhas, Pedrinha da Cré, Ponta da Baía de Nossa Senhora, Cré, Vinha Velha, Ponta do Norte, Airport area, and Ponta Negra (Figure 1). 
As described in the 2016 Appendix of Ávila et al. [19], the Q-values depend on three main geoconservation criteria: A: intrinsic value of the geosite, with a total of nine indicators (A1 to A9); B: potential use of the geosite, with a total of nine indicators (B1 to B9); and C: potential threats, with a total of seven indicators ( $\mathrm{C} 1$ to $\mathrm{C} 7)$. Each parameter is quantified on a scale from 1 to 5 , thus allowing the ranking of the geosites. Two equations are used for the calculation of the $Q$-values:

$$
\begin{gathered}
Q=\frac{\left(2 \sum A+\sum B+1.5 \sum C\right)}{3} \\
Q=\frac{\left(\sum A+\sum B+\sum C\right)}{3}
\end{gathered}
$$

Whenever any of the values attributed to parameters A1, A6, A9, B1 and B2 is $<3$, or whenever any of the values attributed to A3 is $<4$, then Equation (2) is to be used (and thus $Q$-values will have a regional or local relevance); in all other cases, equation (1) is to be used and such geosites will have an international or national relevance (see Appendix of [19]).

In contrast to $Q$-values, for this work we used Brilha's methodology [2], which is based on four geoconservation criteria: (A) Scientific Value (with seven indicators evaluated); (B) Potential Educational Use (12 indicators); (C) Potential Touristic Use (13 indicators) and (D) Degradation Risk (five indicators). Since Santa Maria is a small island with just one municipality, we adapted some of the indicators of Brilha [2] (e.g., distances (in km), population density, economic level) to this insular context. For example, the distances were changed as follows: instead of $50 \mathrm{~km}$, we used $10 \mathrm{~km}$; and instead of $100 \mathrm{~km}$, we used $15 \mathrm{~km}$. Several relevant scientific publications were taken into account (cf. [24-39]; for a review, see [19,40] and references therein) for the attribution of values to each criterion per geosite, and the quantitative evaluation attributed for each indicator was confirmed by experts on the geology and palaeontology of Santa Maria Island, mainly as a result of 14 annual sessions with international workshops on "Palaeontology in Atlantic Islands," held on the island since 2002 (see Tables S1-S4). These quantitative values were converted into rankings (Table 1), which were then compared with $Q$-values [19].
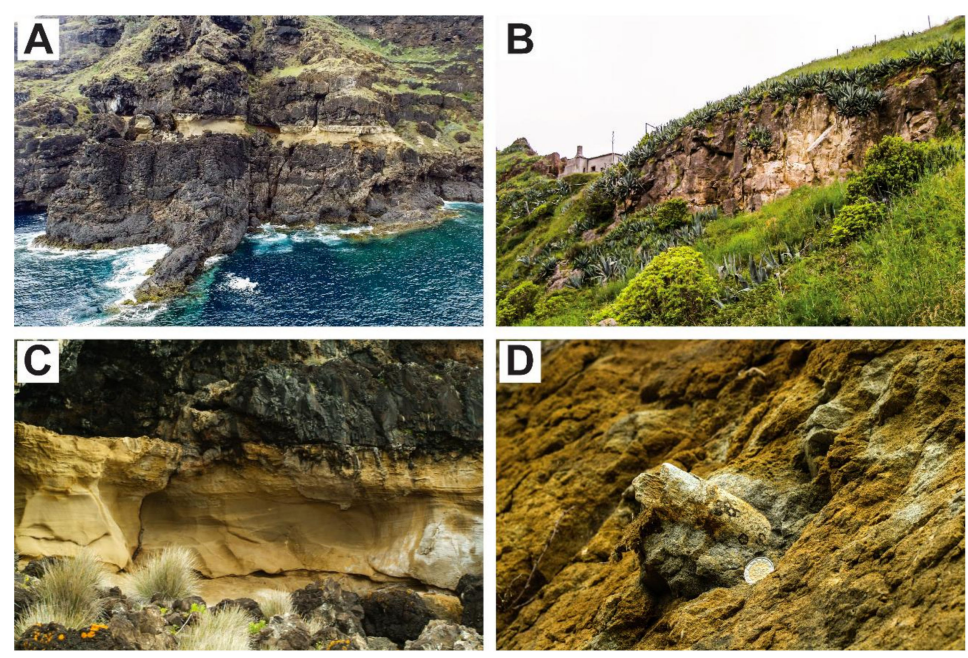

Figure 5. Fossiliferous geosites at Santa Maria Island. (A) Malbusca (Pliocene); (B) Cré (Pliocene); (C) partial view of the Malbusca outcrop; (D) detail of a whale bone at Cré. In Malbusca, a layer of Pliocene fossiliferous marine sediments is encapsulated between two submarine lava flows, with ages ranging between 4.32 Ma (bottom) and 3.59 Ma (top) [50]. Cré is renowned for the presence of fossil remains of whale bones. It is worth highlighting that the occurrence of such remains in volcanic oceanic islands is extremely rare. As a matter of fact, fossil remains of cetaceans are only known from five out of $>20,000$ volcanic oceanic islands worldwide [24,25]. 
Table 1. Comparison of the ranking positions of the 17 Santa Maria Island fossiliferous geosites according to the two methodologies used: the $Q$-values [19], and the present results after Brilha [2].

\begin{tabular}{cccccc}
\hline Fossiliferous & \multicolumn{5}{c}{ Total/Value/Potential Use } \\
\cline { 2 - 5 } Outcrops & $Q[19]$ & $\begin{array}{c}\text { Scientific } \\
\text { Value }\end{array}$ & $\begin{array}{c}\text { Potential } \\
\text { Educational Use }\end{array}$ & $\begin{array}{c}\text { Potential } \\
\text { Touristic Use }\end{array}$ & $\begin{array}{c}\text { Degradation } \\
\text { Risk }\end{array}$ \\
\hline Ponta do Castelo & 1 & 1 & 6 & 7 & 6 \\
Prainha & 2 & 4 & 1 & 1 & 1 \\
Malbusca & 3 & 3 & 12 & 12 & 7 \\
Pedra-que-Pica & 4 & 2 & 5 & 5 & 6 \\
Figueiral & 5 & 10 & 4 & 3 & 4 \\
Pedreira do Campo & 6 & 9 & 2 & 1 & 3 \\
Lagoinhas & 7 & 8 & 5 & 7 & 6 \\
Cré & 8 & 9 & 3 & 4 & 2 \\
Airport Area & 9 & 6 & 7 & 6 & 7 \\
Ponta do Cedro & 10 & 8 & 10 & 9 & 6 \\
Ichnofossils' cave & 11 & 5 & 8 & 8 & 7 \\
Ponta do Norte & 12 & 11 & 9 & 12 & 7 \\
Ponta da Baía de N & 13 & 12 & 14 & 11 & 7 \\
Senhora & 13 & 7 & 11 & 10 & 6 \\
Vinha Velha & 14 & 11 & 13 & 2 & 7 \\
Ponta dos Frades & 15 & 11 & 11 & 12 & \\
Ponta Negra & 16 & 12 & 14 & & 7 \\
Pedrinha da Cré & & & & 9 \\
\hline
\end{tabular}

\section{Results}

The re-evaluation of the 17 fossiliferous outcrops resulted in different values for each criterion (Tables S1-S4). Accordingly, the same geosite occupies distinct rank positions, depending on the criterion evaluated (Table 1). For example, the Ponta do Castelo outcrop is ranked first for Scientific Value, whereas for the remaining criteria (Potential Educational Use, Potential Touristic Use and Degradation Risk), the first position is occupied by the outcrop at Prainha. On the contrary, the geosite that presents the lowest ranking position in all criteria is Pedrinha da Cré. There are no sites with high degradation risk (cf. Table S4, Supplementary Materials), but there are three sites with moderate degradation risk (Prainha, Airport Area and Pedreira do Campo), the remaining 14 sites presenting a low risk of degradation.

Our results (Table 1) show some similarities to those of Ávila et al. [19], mainly regarding scientific value. However, significant differences were detected between the $Q$-values ranking and the rankings obtained for potential educational use, potential touristic use, and degradation risk.

\section{Discussion}

\subsection{Scientific Value}

The similarities observed in the four top-ranked geosites as a result of the two methods of quantitative evaluation $[2,19]$ are mainly related to the high scientific value attributed to those geosites. Ponta do Castelo occupies the first position in the ranking of scientific value because of its rarity at an international level. This geosite represents a shelf tempestite deposit that provided important information about sediment transport and deposition processes on the slope of reefless volcanic oceanic islands [49]. The rapid deposition of these sediments and its posterior cover, and thus preservation, by a lava delta on top, allowed an inference on the coeval water depth $(\sim 55 \mathrm{~m})$ at the time of deposition of the sediments, at about $4.13 \pm 0.19 \mathrm{Ma}$ to $3.96 \pm 0.06 \mathrm{Ma}[23,50]$.

Prainha, a Last Interglacial (Pleistocene: MIS 5e) and very fossiliferous deposit, is ranked second. This easily accessible outcrop provides a secure and interesting visit for tourists, and is certainly one of the best studied geosites in Santa Maria Island [28,40,51-58]. Prainha has abundant fossils 
and ichnofossils and it is well known for the presence of thin beds of the small Semelidae bivalve, Ervilia castanea (Montagu, 1803). Recently, fossil cetacean remains (which are extremely rare on volcanic oceanic islands) were reported from this outcrop [25].

Malbusca is located within a large volcano-sedimentary sequence consisting of pillow lavas and marine fossiliferous sediments of the Touril Volcano-Sedimentary Complex, which were covered by submarine sheet flows and marine (less fossiliferous) sediments of the Pico Alto Complex. The transition to subaerial flows and tuffs occurs at about $130 \mathrm{~m}$ [23]. The thick, very fossiliferous sedimentary package that forms the base of this sequence sits on pillow lavas, attaining a maximum height of about $25 \mathrm{~m}$, and was dated between $4.32 \pm 0.06$ and $4.02 \pm 0.06 \mathrm{Ma}[23,50]$. The transport and deposition of both marine sediments and associated organisms are here associated with storms [39]. In fact, several proximal tempestites (i.e., tempestites located close to shore) are visible throughout the sequence, and the authors inferred the remobilization, transport and deposition of impressive amounts of sediment onshore, under increasing water depths, during a transgression of around $80 \mathrm{~m}[23,39]$. The fossil record at Malbusca is abundant and diversified, containing skeletal remains of 81 specific taxa of cetaceans, fishes, molluscs, echinoids, bryozoans, crustaceans (barnacles, decapods and ostracods), brachiopods, annelids, corals, and coralline and Peyssonneliacean algae forming rhodoliths $[24,26,28,29,33,35-37,39,40]$. The ichnofossil record is also relevant and displays traces made by fishes, echinoderms, annelids and crustaceans (barnacles and decapods) [27,30,31].

Pedra-que-pica is, probably, the largest multi-specific shell bed (coquina) ever described for a volcanic oceanic island. Its original area and volume are estimated to be $>23,000 \mathrm{~m}^{2}$ and 160,000 to $250,000 \mathrm{~m}^{3}$, respectively [32]. This massive fossil shell accumulation is located on the southeastern tip of Santa Maria Island (cf. Figure 1) and corresponds to at least three debris-fall storm-related events that promoted a tri-part accumulation of sediments: a shell coquina in the base, a conglomerate in the middle, and a second shell coquina deposit on top. The biological material, which originated nearby in a shallow and highly productive carbonate factory, is formed mostly of disarticulated bivalve shells, and dominated by small Ostraea spp., with secondary amounts of the large bivalve Gigantopecten latissimus (Brocchi, 1814). The downslope transport and deposition below fair-weather wave base, at around $50 \mathrm{~m}$ depth, as attested by the overlying volcanic succession, illustrates the geological processes involved in the transport and sedimentation of both marine organisms and sediments, that occur on the shelves that surround reefless volcanic oceanic islands [32]. Notwithstanding its massive accumulation of shells, the fossil record at Pedra-que-pica is not as impressive for its biodiversity as that of Malbusca, with fewer specific taxa reported (64 in total): cetaceans, fishes, molluscs, echinoids, bryozoans, crustacean barnacles, brachiopods and corals $[24,26,28,29,32,33,35,40]$. The ichnofossil record includes traces made by echinoderms, annelids, crustacean barnacles and crustacean decapods $[27,30,31]$.

\subsection{Educational and Touristic Potential Uses}

These two criteria have 10 indicators in common (cf. Tables S2 and S3). Although being the same, the weight assigned to each indicator is different, in order to distinguish their relative importance [2]. For tourism purposes, the natural scenario is a critical asset for the utility of the geosite, which is not so relevant for educational purposes. In both criteria, Prainha-a small beach with a landscape of scenic nature, with good conditions of access and safety-occupies the first position. Concerning education, the Prainha geosite is viewed by researchers as an excellent educational resource as it presents several geological elements that can be used at all levels of education from basic to university students. At the tourist level, Pedreira do Campo is also in the first position, which can be justified by a combination of natural and cultural reasons [59], the easy access from various means of transport, the amount of information provided to visitors, and the existence of safety measures (e.g., phone network).

Curiously, the Ponta Negra outcrop ranks in the second position in regard to potential touristic use. This geosite does not present geological elements that require great scientific knowledge to be easily understood, and it is located nearby one of the staging points of the fossil marine tour around 
the island, allowing tourists good and safe access by boat (in São Lourenço bay). Finally, and most importantly, the presence of cetacean remains [24,25], an extremely rare occurrence in oceanic islands, is a tourist attraction with high potential.

\subsection{Degradation Risk}

The Prainha geosite has the highest risk of degradation of all 17 fossiliferous geosites, followed by the Airport Area and Pedreira do Campo, the risks for which are classified as moderate. A good access constitutes an advantage for tourist visitation, but it raises the chances of degradation to the outcrop. Considering that Prainha is the geosite with the highest potential tourist use, it is expected that there will be a higher flow of tourists than to other geosites, thus increasing the anthropogenic pressure and, consequently, increasing the degradation risk of all the geological elements present [60]. The lack of inspection and protection structures might promote the irresponsible collection of fossils that are in good condition [51]. Moreover, Prainha is located in a shallow coastal zone, where all the geological elements are exposed to marine erosion, thus raising the risk of natural degradation. Easy accessibility and the fact that this is a bathing spot make this area the geosite with the greatest threat of destruction, either from natural or anthropogenic origin.

The Airport Area geosite is located on private property and access is conditioned, thus decreasing the degradation risk. The Pedreira do Campo outcrop was the first geosite to be classified as a Natural Regional Monument. Its location nearby to Vila do Porto and access via a rural road grants safe access by motor vehicles. Good accessibility in association with a high tourist potential results in a moderate risk of degradation, mainly from anthropogenic origin.

\subsection{Conservation and Management of Palaeontological Geosites}

By definition, palaeogeographical (palaeoenvironmental) geosites should be designed and implemented in order to preserve the main subtypes of the geological heritage (facies, palaeoecological, ichnological, taphonomic, event, and geoarchaeological), which are present in relevant palaeoenvironments and palaeoecosystems [3]. In the Azores, the palaeontological heritage of Santa Maria Island is protected under four legal instruments. The first to be implemented was the Regional Decree-Law No. 47/2008/A, dated the 7th of November, which created the "Island Nature Park of Santa Maria," which was designed to re-group the Azorean Protected Areas (e.g., Nature Reserves, Regional Natural Monuments) in neighbouring patches under a sole classification based on the categories defined by IUCN [61], thus promoting more efficient management of the island protected areas and fostering biodiversity conservation measures. It was followed by the Regional Decree-Law No. 39/2012/A, dated the 19th of September, which implemented standards for the use and intervention in the fossil deposits of Santa Maria, clarifying the procedures and rules applied to those who wish to intervene or study these areas. On 21 March 2013, the Azores Geopark was accepted as the 53rd European Geopark, and integrated into the European Network of Geoparks. Five out of 15 geosites [47] were then considered at Santa Maria Island as a priority for the development of geoconservation strategies, two of them containing fossils (Pedreira do Campo and Ponta do Castelo). However, a revision of the geosites of this island, with a special focus on its palaeontological heritage, increased the total number of geosites to 26 , two of them considered of international relevance [19]. The importance of Santa Maria's unique palaeontological resources was acknowledged by the International Palaeontological Association, which supported the classification of the entire island as the first worldwide PalaeoPark. This achievement was legally recognized as such by the Regional Government of the Azores, by means of the Regional Decree-Law No. 11/2018/A, dated the 28 August. The "Santa Maria PalaeoPark" was thus implemented aiming to: (1) protect and divulge the rich palaeobiodiversity of (so far) 20 fossiliferous geosites; (2) preserve notable palaeontological and geological elements present on the island; and (3) promote the diversification of the Nature tourism offered in the Azores. Within this context, several projects were implemented during the last decade: the "Fossils Route," a series of four terrestrial trails and one maritime tour around the island, all of 
them exploring the palaeontological touristic resources of the island; and the "House of the Fossils," a Science Centre aiming to divulge the island's palaeontological heritage.

The implementation of the Regional Decree-Laws that protect the fossils of Santa Maria is not always an easy task. Perhaps one of the most difficult situations that politicians and other decision-makers face is choosing which outcrop should be open to visitors, and which should be open only to researchers. In order to take on these management measures, a holistic approach is mandatory, assuring that all relevant criteria for geosite assessment and sustainable geotourism (scientific use, educational potential use, touristic potential use, and degradation risk) are fully screened, thus allowing an informed consensus on these matters (cf. $[9,16,18,62]$ ). The "Santa Maria PalaeoPark" has a formal consulting board, with members designated by the International Palaeontological Association and by the University of the Azores, whose scientific expertise should be an invaluable asset to assist a more informed decision on possible controversies regarding the societal use of the fossiliferous outcrops of Santa Maria.

The main differences between our results and those of Ávila et al. [19] are in regard to the potential tourist and educational uses, which, when evaluated independently as we did, and following other criteria [2], result in quite different positions about the intrinsic value of the geosite (Table 1). In the first work [19], geosites with high scientific value have an international relevance, so the potential tourist and educational uses do not carry such a high weight in the final result. The absence of equations to obtain a final result and the independence of each criterion distinguishes the geosites for what they represent, making it useful for the political decision of management strategies $[63,64]$, according to the purpose intended. As proposed [2], the value of a geosite is not directly related to its vulnerability. However, for management measures to be applied, it is necessary to evaluate all criteria in parallel, so that the final decision is as rational as possible.

\section{Conclusions}

The fossiliferous deposits of Santa Maria are fundamental sources of information regarding the geological history of the island and its associated biological evolution, which makes them important for a wide spectrum of researchers. Considering their value to the scientific community and also to the island inhabitants and visitors, these sites should be preserved for present and future generations [5]. In order to define geoconservation priorities, it is necessary to evaluate several aspects independently, according to what each geosite represents to society. Geosites with high scientific value should be preserved independently of their immediate use, which, for places with high resources for education or tourism, is only justified by its utility.

Prainha has a high scientific value but it is also the outcrop with greater risk of degradation, justifying reasons why it must have a greater conservation priority. Pedreira do Campo presents a moderate risk of degradation and the greatest potential touristic use, becoming a priority geosite for tourism strategic purposes $[65,66]$. Ponta do Castelo is the geosite with the highest scientific value in both analysis ([19], this work), and must therefore be preserved independently of the remaining criteria. In the case of the Airport area, although there is a risk of degradation higher than for most of the other 16 outcrops, its intrinsic value is not so relevant at the moment to the scientific community and is not a determining factor for its conservation.

The results obtained from this work suggest that the application of new evaluation methodologies can be a useful tool in land-use planning policies and Nature conservation measures. The independent numerical evaluation for each criterion enables the individual analysis of each geosite and reduces (but does not eliminate) the subjectivity associated with the evaluation processes [2].

The geodiversity and the landscape nature present at these geosites warrant their potential uses for touristic and educational purposes. These uses have been applied to the island, such as found in the "House of the Fossils," where the permanent exhibition features scientific results published over the last years, displayed in a didactic, interactive and easily understandable way for visitors; on the production of tourism resources, such as the "Fossils Route," which reflect the palaeontological highlights of the 
island; and finally, in the newly formed "Santa Maria PalaeoPark," which simultaneously protects and promotes the sustainable touristic use of palaeontological heritage on Santa Maria Island. Together, these initiatives make this island a good example of a successful joint venture between science, political decision-makers, geoconservation management strategies, sustainable tourism, and education.

Supplementary Materials: The following are available online at http:/ /www.mdpi.com/2071-1050/10/10/3596/s1, Table S1: Numerical assessment of scientific value. The letters A, B, C, D, E, F, G regard to representativeness, key locality, scientific knowledge, integrity, geological diversity, rarity and use limitations, respectively; Table S2: Numerical assessment of potential educational value. The letters A, B, C, D, E, F, G, H, I, J, K, L represent vulnerability, accessibility, use limitations, safety, logistics, density of population, association with other values, scenery, uniqueness, observation conditions, didactic potential and geological diversity, respectively; Table S3: Numerical assessment of potential touristic value. The letters A, B, C, D, E, F, G, H, I, J, K, L, M represent vulnerability, accessibility, use limitations, safety, logistics, density of population, association with other values, scenery, uniqueness, observation conditions, interpretative potential, economic level and proximity of recreational areas, respectively; Table S4: Numerical assessment of degradation risk. The letters A, B, C, D, E represent deterioration of geological elements, proximity to areas/activities with potential to cause degradation, legal protection accessibility and density of population, respectively. Geosites with a final value (last column) $<200$ are considered at low degradation risk; those with final values between 201 and 300 are considered at moderate degradation risk; those with final values $>300$ are considered at high degradation risk.

Author Contributions: Conceptualization, V.B.R., C.S.M. and S.P.Á.; Funding acquisition, S.P.Á.; Investigation, V.B.R., C.S.M., A.V. and S.P.Á.; Methodology, V.B.R. and S.P.Á.; Project administration, S.P.Á.; Resources, R.C., J.P. and S.P.Á.; Supervision, A.V. and S.P.Á.; Validation, V.B.R. and S.P.Á.; Writing-original draft, V.B.R.; Writing-review \& editing, V.B.R., C.S.M., L.S., A.V., R.C., J.P., M.E.J. and S.P.Á.

Funding: This research was funded by Direção Regional da Ciência, Tecnologia e Comunicações (Regional Government of the Azores), and by FCT (Fundação para a Ciência e Tecnologia) of the Portuguese Government. CSM was funded by a Ph.D. grant M3.1.a/F/100/2015 from FRCT/Açores 2020 (FRCT-Fundo Regional para a Ciência e Tecnologia). SPA acknowledges his "Investigador FCT" contract (IF/00465/2015), funded by FCT. We also acknowledge funding from FEDER through the Operational Programme for Competitiveness Factors-COMPETE and from FCT under UID/BIA/50027/2013 and POCI-01-0145-FEDER-006821 projects, and under DRCT-M1.1.a/005/Funcionamento-C-/2016 (CIBIO-A) project from FRCT.

Acknowledgments: We thank Clube Naval de Santa Maria and Câmara Municipal da Vila do Porto for field assistance. We are grateful to the organizers and participants of the 14 editions of the International Workshop 'Paleontology in Atlantic Islands'. We also thank the four anonymous reviewers, whose comments helped improving this manuscript.

Conflicts of Interest: The authors declare no conflict of interest. The funders had no role in the design of the study; in the collection, analyses, or interpretation of data; in the writing of the manuscript, and in the decision to publish the results.

\section{References}

1. Gray, M. Geodiversity: Valuing and Conserving Abiotic Nature; John Wiley \& Sons: Blackwell, UK, 2013; pp. 1-512. ISBN 978-0-470-74215-0.

2. Brilha, J. Inventory and quantitative assessment of geosites and geodiversity sites: A review. Geoheritage 2016, 8, 119-134. [CrossRef]

3. Bruno, D.E.; Crowley, B.E.; Gutak, J.M.; Moroni, A.; Nazarenko, O.V.; Oheim, K.; Ruban, D.A.; Tiess, G.; Zorina, S.O. Paleogeography as geological heritage: Developing geosite classification. Earth-Sci. Rev. 2014, 138, 300-312. [CrossRef]

4. Reynard, E.; Fontana, G.; Kozlik, L.; Scapozza, C. A method for assessing the scientific and additional values of geomorphosites. Geogr. Helv. 2007, 62, 148-158. [CrossRef]

5. Henriques, M.H.; Pena dos Reis, R.; Brilha, J.; Mota, T. Geoconservation as an emerging geoscience. Geoheritage 2011, 3, 117-128. [CrossRef]

6. Sharples, C. Concepts and Principles of Geoconservation; Tasmanian Parks \& Wildlife Service: Hobart, Australia, 2002; pp. 1-179.

7. Prosser, C.D. Our rich and varied geoconservation portfolio: The foundation for the future. Proc. Geol. Assoc. 2013, 124, 568-580. [CrossRef]

8. Prosser, C.D.; Brown, E.J.; Jonathan, G.L.; Bridgland, D.R. Geoconservation for science and society-An agenda for the future. Proc. Geol. Assoc. 2013, 124, 561-567. [CrossRef] 
9. Dowling, R.K. Global geotourism-An emerging form of sustainable tourism. Czech J. Tour. 2013, 2, 59-79. [CrossRef]

10. Bruschi, V.M.; Cendrero, A. Geosite evaluation: Can we measure intangible values? Il Quaternario 2005, 18, 293-306.

11. Serrano, E.; González-Trueba, J.J. Assessment of geomorphosites in natural protected areas: The Picos de Europa National Park (Spain). Géomorphol. Relief Process. Environ. 2005, 3, 197-208. [CrossRef]

12. Coratza, P.; Bruschi, V.; Piacentini, D.; Saliba, D.; Soldati, M. Recognition and assessment of Geomorphosites in Malta at the Il-Majjistral Natural and History Park. Geoheritage 2011, 3, 175-185. [CrossRef]

13. Pereira, D.I.; Pereira, P.; Brilha, J.; Cunha, P.P. The Iberian Massif Landscape and Fluvial Network in Portugal: A geoheritage inventory based on the scientific value. Proc. Geol. Assoc. 2015, 126, 252-265. [CrossRef]

14. Reynard, E.; Perret, A.; Bussard, J.; Grangier, L.; Martin, S. Integrated Approach for the Inventory and Management of Geomorphological Heritage at the Regional Scale. Geoheritage 2016, 8, 43-60. [CrossRef]

15. Cappadonia, C.; Coratza, P.; Agnesi, V.; Soldati, M. Malta and Sicily Joined by Geoheritage Enhancement and Geotourism within the Framework of Land Management and development. Geosciences 2018, 8, 253. [CrossRef]

16. Dowling, R.K.; Newsone, D. (Eds.) Geotourism; Elsevier: London, UK, 2005; pp. 1-352. ISBN 978-0-7506.

17. Kubalíková, L.; Kirchner, K. Geosite and geomorphosite assessment as a tool for geoconservation and geotourism purposes: A case study from Vizovická vrchovina Highland (Eastern part of the Czech Republic). Geoheritage 2016, 8, 5-14. [CrossRef]

18. Hose, T.A. European Geotourism-Geological Interpretation and Geoconservation Promotion for Tourists. In Geological Heritage: Its Conservation and Management; Barretino, D., Wimbledon, W.A.P., Gallego, E., Eds.; Sociedad Geológica de España/Instituto Tecnológico GeoMinero de España/ProGEO: Madrid, Spain, 2000; pp. 127-146. ISBN 84-7840-417-1.

19. Ávila, S.P.; Cachão, M.; Ramalho, R.S.; Botelho, A.Z.; Madeira, P.; Rebelo, A.C.; Cordeiro, R.; Melo, C.; Hipólito, A.; Ventura, M.A.; et al. The palaeontological heritage of Santa Maria Island (Azores: NE Atlantic): A re-evaluation of geosites in GeoPark Azores and their use in geotourism. Geoheritage 2016, 8, 155-171. [CrossRef]

20. Laughton, A.S.; Whitmarsh, R.B. The Azores-Gibraltar plate boundary. In Geodynamics of Iceland and the North Atlantic Area; Kristjansson, L., Ed.; Riedel: Kufstein, Austria, 1974; pp. 63-81.

21. Searle, R. Tectonic pattern of the Azores spreading centre and triple junction. Earth Planet. Sci. Lett. 1980, 51, 415-434. [CrossRef]

22. Needham, H.D.; Francheteau, J. Some characteristics of the rift valley in the Atlantic Ocean near $36^{\circ} 48^{\prime}$ north. Earth Planet. Sci. Lett. 1974, 22, 29-43. [CrossRef]

23. Ramalho, R.S.; Helffrich, G.; Madeira, J.; Cosca, M.; Thomas, C.; Quartau, R.; Hipólito, A.; Rovere, A.; Hearty, P.J.; Ávila, S.P. Emergence and evolution of Santa Maria Island (Azores)—The conundrum of uplifted islands revisited. Geol. Soc. Am. Bull. 2017, 129, 372-390. [CrossRef]

24. Estevens, M.; Ávila, S.P. Fossil whales from the Azores. Açoreana 2007, Supl. 5, 140-161.

25. Ávila, S.P.; Cordeiro, R.; Rodrigues, A.R.; Rebelo, A.C.; Melo, C.S.; Madeira, P.; Pyenson, N.D. Fossil Mysticeti from the Pleistocene of Santa Maria Island, Azores (Northeast Atlantic Ocean), and the prevalence of fossil cetaceans on oceanic islands. Palaeontol. Electron. 2015, 18, 1-12. [CrossRef]

26. Ávila, S.P.; Ramalho, R.; Vullo, R. Systematics, palaeoecology and palaeobiogeography of the Neogene fossil sharks from the Azores (Northeast Atlantic). Annales de Paléontologie 2012, 98, 167-189. [CrossRef]

27. Uchman, A.; Torres, P.; Johnson, M.E.; Berning, B.; Ramalho, R.S.; Rebelo, A.C.; Melo, C.S.; Baptista, L.; Madeira, P.; Cordeiro, R.; et al. Feeding traces of recente ray fish and occurrences of the trace fossil Piscichnus waitemata from the Pliocene of Santa Maria Island, Azores (Northeast Atlantic). Palaios 2018, 33, 361-375. [CrossRef]

28. Madeira, P.; Kroh, A.; Cordeiro, R.; Meireles, R.; Ávila, S.P. The fossil echinoids of Santa Maria Island, Azores (Northern Atlantic Ocean). Acta Geol. Pol. 2011, 61, 243-264.

29. Winkelmann, K.; Buckeridge, J.S.; Costa, A.C.; Dionísio, M.A.M.; Medeiros, A.; Cachão, M.; Ávila, S.P. Zullobalanus santamariaensis sp. nov. a new late Miocene barnacle species of the family Archeobalanidae (Cirripedia: Thoracica), from the Azores. Zootaxa 2010, 2680, 33-44. 
30. Uchman, A.; Quintino, V.; Rodrigues, A.M.; Johnson, M.E.; Melo, C.; Cordeiro, R.; Ramalho, R.S.; Ávila, S.P. The trace fossil Diopatrichnus santamariaensis nov. isp.-A shell armoured tube from Pliocene sediments of Santa Maria Island, Azores (NE Atlantic Ocean). Geobios 2017, 50, 459-469. [CrossRef]

31. Uchman, A.; Johnson, M.E.; Rebelo, A.C.; Melo, C.; Cordeiro, R.; Ramalho, R.S.; Ávila, S.P. Vertically-oriented trace fossil Macaronichnus segregatis from Neogene of Santa Maria Island (Azores; NE Atlantic) records vertical fluctuations of the coastal groundwater mixing zone on a small oceanic island. Geobios 2016, 49, 229-241. [CrossRef]

32. Ávila, S.P.; Ramalho, R.S.; Habermann, J.M.; Quartau, R.; Kroh, A.; Berning, B.; Johnson, M.E.; Kirby, M.X.; Zanon, V.; Titschack, J.; et al. Palaeoecology, taphonomy, and preservation of a lower Pliocene shell bed (coquina) from a volcanic oceanic island (Santa Maria Island, Azores). Palaeogeogr. Palaeoclimatol. Palaeoecol. 2015, 430, 57-73. [CrossRef]

33. Ávila, S.P.; Melo, C.; Berning, B.; Cordeiro, R.; Landau, B.; Da Silva, C.M. Persististrombus coronatus (Mollusca: Strombidae) in the early Pliocene of Santa Maria Island (Azores: NE Atlantic): Palaeoecology, palaeoclimatology and palaeobiogeographic implications on the NE Atlantic Molluscan Biogeographical Provinces. Palaeogeogr. Palaeoclimatol. Palaeoecol. 2016, 441, 912-923. [CrossRef]

34. Janssen, A.W.; Kroh, A.; Ávila, S.P. Early Pliocene heteropods and pteropods (Mollusca, Gastropoda) from Santa Maria (Azores, Portugal): Systematics and biostratigraphic implications. Acta Geol. Pol. 2008, 58, 355-369.

35. Kroh, A.; Bitner, M.A.; Ávila, S.P. Novocrania turbinata (Brachiopoda) from the Early Pliocene of the Azores (Portugal). Acta Geol. Pol. 2008, 58, 473-478.

36. Meireles, R.P.; Faranda, C.; Gliozzi, E.; Pimentel, A.; Zanon, V.; Ávila, S.P. Late Miocene marine ostracods from Santa Maria Island, Azores (NE Atlantic): Systematics, palaeoecology and palaeobiogeography. Révue de Micropaléontologie 2012, 55, 133-148. [CrossRef]

37. Rebelo, A.C.; Rasser, M.W.; Riosmena-Rodríguez, R.; Neto, A.I.; Ávila, S.P. Rhodolith forming coralline algae in the Upper Miocene of Santa Maria Island (Azores, NE Atlantic): A critical evaluation. Phytotaxa 2014, 190, 370-382. [CrossRef]

38. Rebelo, A.C.; Meireles, R.P.; Barbin, V.; Neto, A.I.; Melo, C.; Ávila, S.P. Diagenetic history of lower Pliocene rhodoliths of the Azores archipelago (NE Atlantic): Application of cathodoluminescence techniques. Micron 2016, 80, 112-121. [CrossRef] [PubMed]

39. Rebelo, A.C.; Rasser, M.W.; Kroh, A.; Johnson, M.E.; Ramalho, R.S.; Melo, C.; Uchman, A.; Berning, B.; Silva, L.; Zanon, V.; et al. Rocking around a volcanic island shelf: Pliocene rhodolith beds from Malbusca, Santa Maria Island (Azores, NE Atlantic). Facies 2016, 62, 1-31. [CrossRef]

40. Ávila, S.P.; Ramalho, R.; Habermann, J.; Titschack, J. The marine fossil record at Santa Maria Island (Azores). In Volcanoes of the Azores. Revealing the Geological Secrets of the Central Northern Atlantic Islands. Active Volcanoes of the World; Kueppers, U., Beier, C., Eds.; Springer: Berlin, Germany, 2018; pp. 155-196.

41. Lima, E. Património Geológico dos Açores: Valorização de Locais com Interesse Geológico das Áreas Ambientais, Contributo Para o Ordenamento do Território. Master's Thesis, Universidade dos Açores, Ponta Delgada, Portugal, 2007. (In Portuguese)

42. Nunes, J.C.; Lima, E.A.; Ponte, D.; Costa, M.P.; Castro, R. Azores Geopark Application; Azores Geopark: Horta, Portugal, 2011; pp. 1-50. Available online: http:/ / www.azoresgeopark.com/media/docs/candidatura_ga/ Application.pdf (accessed on 15 May 2018).

43. Lima, E.A.; Nunes, J.C.; Costa, M.P.; Machado, M. Basis for the geological heritage management in the Azores Archipelago (Portugal). J. Integr. Coast. Zone Manag. 2014, 14, 301-319. [CrossRef]

44. Lima, E.A.; Nunes, J.C.; Medeiros, S. Divulgação do património geológico da ilha de Santa Maria. Relatórios e Comunicações do Departamento de Biologia 2009, 36, 19-27. (In Portuguese)

45. Nunes, J.C.; Lima, E.A.; Medeiros, S. Carta de Geossítios da ilha de Santa Maria (Açores). Escala 1:50,000; Departamento de Geociências, Universidade dos Açores: Ponta Delgada, Portugal, 2008. (In Portuguese)

46. Brilha, J.B. Património Geológico e Geoconservação: A Conservação da Natureza na sua Vertente Geológica; Palimage Editores: Viseu, Portugal, 2005; pp. 1-190, (In Portuguese). ISBN 972-8575-90-4.

47. Bruschi, V.M.; Cendrero, A.; Albertos, J.A.C. A statistical approach to the validation and optimization of geoheritage assessment procedures. Geoheritage 2011, 3, 131-149. [CrossRef]

48. Fassoulas, C.; Mouriki, D.; Dimitriou-Nikolakis, P.; Iliopoulos, G. Quantitative assessment of geotopes as an effective tool for geoheritage management. Geoheritage 2012, 4, 177-193. [CrossRef] 
49. Meireles, R.P.; Quartau, R.; Ramalho, R.S.; Rebelo, A.C.; Madeira, J.; Zanon, V.; Ávila, S.P. Depositional processes on oceanic island shelves-Evidence from storm-generated Neogene deposits from the mid-North Atlantic. Sedimentology 2013, 60, 1769-1785. [CrossRef]

50. Sibrant, A.L.R.; Hildenbrand, A.; Marques, F.O.; Costa, A.C.G. Volcano-tectonic evolution of the Santa Maria Island (Azores): Implications for paleostress evolution at the western Eurasia-Nubia plate boundary. J. Volcanol. Geotherm. Res. 2015, 291, 49-62. [CrossRef]

51. Ávila, S.P.; Rebelo, A.C.; Medeiros, A.; Melo, C.S.; Gomes, C.; Bagaço, L.; Madeira, P.; Borges, P.A.; Monteiro, P.; Cordeiro, R.; et al. Os fósseis de Santa Maria (Açores): A jazida da Prainha; OVGA-Observatório Vulcanológico e Geotérmico dos Açores: Lagoa, Portugal, 2010. (In Portuguese)

52. Ávila, S.P.; Amen, R.; Azevedo, J.M.N.; Cachão, M.; García-Talavera, F. Checklist of the Pleistocene marine molluscs of Prainha and Lagoinhas (Santa Maria Island, Azores). Açoreana 2002, 9, 343-370.

53. Ávila, S.P.; Madeira, P.; García-Talavera, F.; Da Silva, C.M.; Cachão, M.; Martins, A.M.F. Luria lurida (Mollusca: Gastropoda), a new record for the Pleistocene of Santa Maria (Azores, Portugal). Arquipélago 2007, 24, 53-56.

54. Ávila, S.P.; Madeira, P.; Da Silva, C.M.; Cachão, M.; Landau, B.; Quartau, R.; Martins, A.M.F. Local disappearance of bivalves in the Azores during the last glaciation. J. Quat. Sci. 2008, 23, 777-785. [CrossRef]

55. Ávila, S.P.; Madeira, P.; Mendes, N.; Rebelo, A.C.; Medeiros, A.; Gomes, C.; García-Talavera, F.; Da Silva, C.M.; Cachão, M.; Hillaire-Marcel, C.; et al. Mass extinctions in the Azores during the last glaciation: Fact or myth? J. Biogeogr. 2008, 35, 1123-1129. [CrossRef]

56. Ávila, S.P.; Madeira, P.; Zazo, C.; Kroh, A.; Kirby, M.; da Silva, C.M.; Cachão, M.; Martins, A.M.F. Palaeoecology of the Pleistocene (MIS 5.5) outcrops of Santa Maria Island (Azores) in a complex oceanic tectonic setting. Palaeogeogr. Palaeoclimatol. Palaeoecol. 2009, 274, 18-31. [CrossRef]

57. Ávila, S.P.; da Silva, C.M.; Schiebel, R.; Cecca, F.; Backeljau, T.; Martins, A.M.F. How did they get here? Palaeobiogeography of the Pleistocene marine molluscs of the Azores. Bull. Geol. Soc. Fr. 2009, 180, $201-213$. [CrossRef]

58. Ávila, S.P.; Melo, C.; Silva, L.; Ramalho, R.; Quartau, R.; Hipólito, A.; Cordeiro, R.; Rebelo, A.C.; Madeira, P.; Rovere, A.; et al. A review of the MIS 5e highstand deposits from Santa Maria Island (Azores, NE Atlantic): Palaeobiodiversity, palaeoecology and palaeobiogeography. Quat. Sci. Rev. 2015, 114, 126-148. [CrossRef]

59. Cachão, M.; Madeira, J.; Marques Da Silva, C.; Azevedo, J.M.N.; Cruz, A.P.; Garcia, C.; Sousa, F.; Melo, J.; Aguiar, M.; Silva, P.; et al. Pedreira do Campo (Santa Maria, Açores): Monumento natural. Ciências da Terra (UNL) 2003, $V$, 120-123. (In Portuguese)

60. Fuertes-Gutiérrez, I.; García-Ortiz, E.; Fernández-Martínez, E. Anthropic threats to geological heritage: Characterization and management: A case study in the dinosaur tracksites of La Rioja (Spain). Geoheritage 2016, 8, 135-153. [CrossRef]

61. Dudley, N. Guidelines for Applying Protected Area Management Categories; IUCN: Gland, Switzerland, 2008; p. 86. ISBN 978-2-8317-1086-0.

62. Pralong, J.P. A method for assessing the tourist potential and use of geomorphological sites. Géomorphol. Relief Process. Environ. 2005, 3, 189-196. [CrossRef]

63. Clifton, D.; Amran, A. The stakeholder approach: A sustainability perspective. J. Bus. Ethics 2011, 98, 121-136. [CrossRef]

64. Fraga, V. Azores tourism: A development and marketing strategy. Worldw. Hosp. Tour. Themes 2016, 8, 705-710. [CrossRef]

65. Valls, J.-P.; Porta, F. Sustainable tourism and economy; Territory and heritage. Tour. Rev. 1997, 52, 3-10. [CrossRef]

66. Dávid, L. Tourism ecology: Towards the responsible, sustainable tourism future. Worldw. Hosp. Tour. Themes 2011, 3, 210-216. [CrossRef]

(C) 2018 by the authors. Licensee MDPI, Basel, Switzerland. This article is an open access article distributed under the terms and conditions of the Creative Commons Attribution (CC BY) license (http:/ / creativecommons.org/licenses/by/4.0/). 